\title{
Ontogenetic Changes in Azoxyglycoside Levels in the Leaves of Dioon edule Lindl
}

\author{
Alberto Prado, Gabriel Rubio-Mendez, Laura Yañez-Espinosa, Jacqueline C. Bede
}

\begin{abstract}
Plants have multiple strategies, including phytochemicals that protect their vulnerable tissues against pathogens and herbivores. Dioon edule, like all cycads, possess unique azoxy-type compounds, azoxyglycosides (AZGs) as a chemical defense; however, the ontogenetic variability of these compounds in this long-lived cycad is unknown. Here, we investigated the effects of plant age, sex, genotype and individual heterozygosity on AZG levels in mature leaves of wild D. edule populations from eastern Mexico. Individuals were divided into three ontogenetic stages: seedlings, juveniles and adults. We established overall leaf quality by quantifying pigments associated with photosynthesis; chlorophyll $\mathrm{a}_{\mathrm{a}}$, chlorophyll $\mathrm{b}_{\mathrm{b}}$ and lutein. Leaf chlorophyll $\mathrm{l}_{\mathrm{a}}$ levels were higher in seedlings compared to adult cycads. Plants were genotyped using 11 microsatellite markers and foliar AZG levels were quantified by HPLC. AZG levels do not correlate with plant genotype or the individual's heterozygosity. Genetic analysis identified a distinction between lowland and highland individuals; foliar AZG levels were higher in lowland adult cycads compared to highland individuals. In both populations, the highest AZG levels were found in seedlings compared to adult cycads. These young cycads are highly reliant on their few leaves since seedlings bear one or two leaves for the first years of their life and, thus, are unlikely to recover from defoliation. The results suggest that cycad leaves with a greater nutritive content and a higher value for long-term survival are better protected with higher AZG levels. Female adult cycads have higher AZG levels compared to males, suggesting that the benefits of defense could also be linked to reproductive costs.
\end{abstract}

\section{Keywords}

\section{Azoxyglycosides Dioon edule Heterozygosity Ontogeny Specialized metabolism}

\section{Introduction}

Plants are protected against herbivores in various ways, including specialized (secondary) metabolites that act as deterrents or toxins (Schoonhoven and Van Loon 2005). Both the biosynthesis and, if necessary, storage of defensive phytochemicals use resources that could otherwise be used for growth and reproduction (Stamp 2003). Therefore, there are trade-offs between the metabolic flux into growth or defense, which change throughout plant ontogeny reflecting shifts in developmental and reproductive priorities (Boege and Marquis 2005). Two main processes associated with plant ontogeny influence resource allocation: changes in plant size (i.e., increase in the resource acquisition organs like roots and leaves), and shifts from growth to reproductive priorities (Boege and Marquis 2005; Stamp 2003; Weiner 2004). Therefore, to understand a plant's chemical defensive strategy, one must take into account its ontogenetic trajectory.

Depending on the species, specialized metabolites that are part of plant defenses may increase or decrease as plants age (Boege 2005; Bowers and Stamp 1993; Dominy et al. 2003; Goodger et al. 2004; Schappert and Shore 2000; Van Dam et al. 2001). One theory that accounts for these apparent differences is that trade-offs between costs and benefits are specific to particular metabolites and reflect the plant's life history traits. 
As part of life history traits, reproductive strategy often affects resource allocation into plant defenses; gender-related phytochemical differences have been described for several dioecious species (Lloyd and Webb 1977; Obeso 2002). Due to higher investments associated with female reproduction, male dioecious plants tend to grow faster than females (Lloyd and Webb 1977). For example, slow-growing females of the dioecious tree, Acer negundo, invest more in the protection of their leaves and are more resistant to insect herbivory compared to faster-growing males (Jing and Coley 1990).

Plant genotype also may impact phytochemical levels (Wimp et al. 2007). Spatial variation in phytochemical defense can reflect genetic background and genetic diversity (i.e., inbred vs. outbred) (Strauss et al. 2002). Recombination levels and allele segregation that relate to sexual reproduction can influence plant susceptibility to insect herbivores (Johnson et al. 2009). Several studies have shown that inbred plants are more susceptible to herbivory than outbreeding species (Bello-Bedoy and NúñezFarfán 2011; Johnson et al. 2009; Kariyat et al. 2013).

In addition, environmental factors, such as altitude, may influence specialized metabolite content affecting the suitability of hosts for insect herbivores (Rasmann et al. 2014). Erelli et al. (1998) measured lower leaf tannins in the leaves of Betula papyrifera at high elevation sites, which were coupled with a higher growth rate of insect larvae. Rasmann et al. (2014) measured lower herbivory rates and higher flavonoid levels at high elevations, but found no clear trend for other specialized metabolites.

Cycads provide a unique system for investigating ontogenetic, altitudinal, and sex-linked changes in chemical defense; they are dioecious, extremely long-lived species that periodically produce flushes of long-lived leaves, with recorded leaf life times of up to 10 years (Norstog and Nicholls 1997). Cycad pulses of leaf flushes are intercalated with cone formation in both males and females (Norstog and Nicholls 1997), and different reproductive costs between males and females have been identified in a few species (Clark and Clark 1988; Ornduff 1987; Vovides 1990). Clark and Clark (1988) found that the costs associated with female reproduction heavily depress leaf production (Clark and Clark 1988). These costs are reflected in strong differences in the frequencies of cone production between male and female cycads.

Cycads are protected against herbivory by toxic and unique azoxy-type compounds (Norstog and Nicholls 1997). Azoxy compounds are extremely rare in nature, and only have been found in few organisms: Strepotmyces produce azoxylipids, some Entomophthora spp. produce azoxybenzene, and cycads produce azoxyglycosides (AZGs) (Claydon 1978; Ding et al. 2012; Norstog and Nicholls 1997). The mutagenic and carcinogenic properties of AZGs are well documented and have been validated in bacterial, animal, and plant models (Laqueur and Spatz 1968; Matsushima et al. 1979; Teas and Dyson 1967). However, these toxic phytochemicals can be overcome by specialist insects that not only are able to survive on cycad leaves but sequester host-derived AZGs for their own defense (Bowers and Larin 1989; Castillo-Guevara and Rico-Gray 2003; Clark and Clark 1991; Prado et al. 2011, 2014). Specialist herbivores prefer newly emerged leaves (10-100 days old) and have mechanisms that prevent AZG cleavage, and/or detoxify these compounds (Prado et al. 2014; Teas et al. 1966). Nonetheless, high AZG levels in the youngest leaves ( $<10$ days) of the cycad Zamia stevensonii limit herbivory by specialist insects; in contrast, fully expanded leaves (>100 days) are protected by leaf toughness, a mechanical defense (Prado et al. 2014).

Given that ontogeny, gender and genotype might affect the costs and benefits associated with defense, the objectives of this research were to investigate the levels of the defensive AZG in the leaves of the slow-growing, dioecious cycad, Dioon edule. We determined 1) ontogenetic changes in AZG levels in fully developed cycad leaves, 2) sex-related differences in AZG between adult female and male cycads, 
3) if plant genotype and individual heterozygosity correlate with variations in AZG levels, and 4) if the genetic structure of the populations could explain AZG levels. Based on our current understanding of $D$. edule life history, we hypothesized that AZG levels are highest in younger plants to ensure protection of leaves that are critical to reach the next ontogenetic stage. In adults, due to differences in reproductive costs, we hypothesized that AZG investments differ between sexes. We speculate that plant genotype correlates strongly with AZG production, and that individuals exhibiting a higher level of heterozygosity have higher AZG levels.

\section{Methods and Materials}

Dioon edule Lindl. (family Zamiaceae) is a medium-sized cycad endemic to eastern Mexico. The population structure for D. edule is an inverse "J" curve or a Deevey type III curve (Deevey 1947) with high mortality during the first years of life (Vovides 1990). Therefore, only a small proportion of individuals reach sexual maturity; however, a small fraction of these adults survive for the extraordinary period of more than 2000 years (Rubio-Méndez 2010; Vovides 1990). Gender differences associated with reproduction costs are reflected in frequencies of cone production (Vovides 1990); between 2.8-8.8 years in males compared to 10.0-52.0 years in females. Major environmental stresses for this species are prolonged drought, fire, and insect herbivory (Mora et al. 2013; Vovides 1990; Yáñez-Espinosa et al. 2014). Generalist insect herbivores are not observed on cycads (Clark and Clark 1991; Prado et al. 2014). However, specialist herbivore insects that feed on D. edule include the seed-boring erotylid beetles (previously ascribed to Languriidae) in the genus Pharaxonotha, the leaffeeding lycaenid caterpillars Eumaeus debora Hbn. and E. childrenae G. Gray, and, occasionally, the aulacoscelidine beetle Aulacoscelis vogti Monrós (Mora et al. 2013; Prado et al. 2011; Vovides 1990; Yáñez-Espinosa et al. 2014).

\section{Distribution of Dioon edule Lindl}

Dioon edule has a north-south distribution along the Sierra Madre Oriental, with a range of almost $1600 \mathrm{~km}$. Distinct populations can be found in the states of Tamaulipas, San Luis Potosí, Querétaro, Hidalgo and Veracruz (González-Astorga et al. 2003; Mora et al. 2013; Vovides 1990;

Whitelock 2004). The altitudinal range for this species is from sea level to $1525 \mathrm{~m}$ above sea level (masl), growing mostly in tropical deciduous thorn forest and oak forest and rarely in grasslands. The study area is located in the southern part of the State of San Luis Potosí, an area known as Huasteca Potosina. The area is characterized by calcareous rock formations, calcareous and clayey-soils and a semi-warm humid climate (Puig 1976). Large stands of D. edule are found on the slopes and tops of mountains as part of the understory of tropical deciduous forests and oak forests (Quercus laeta Liebm).

\section{Sample Collection}

Leaves were collected from cycads growing between 388 and 1058 masl; tropical deciduous thorn forest occurred at the lower sites and oak forest at the higher sites (Table 1 , Fig. 1). Leaf samples were collected from seven different populations previously characterized demographically by Rubio-Méndez (2010). These populations are spread across an area of approximately $2750 \mathrm{~km}^{2}$. At each location, 21 individuals, including 7 seedlings, 7 juveniles and 7 adults $(N=147$ total), were chosen based on the presence of healthy leaves and with a minimum of $20 \mathrm{~m}$ between adjacent samples. Ontogenetic stages were defined according to protocols of Rubio-Méndez (2010) as follows: seedlings were defined as individuals lacking an above ground stem bearing only one leaf; juveniles are individuals lacking an above ground stem but producing crowns (flushes) of leaves of more than two leaves; and adults were defined as individuals that have a visible above ground stem and produce flushes of leaves composed of 
more than three leaves. When present, live or senesced reproductive structures were used to assign the sex of adult plants. The total number of leaves, the length of the longest leaf, stem height, stem diameter and number of previous crowns of leaves were recorded. The number of previous crowns, a proxy for plant age (Vovides 1990), was counted using the number of girdling leaf traces. A healthy fully toughened mature leaf was selected from each plant. The leaf was cut into segments, keeping leaflets attached to the rachis, and placed on silica gel flakes on ice and brought back to the laboratory where it was kept at $-20{ }^{\circ} \mathrm{C}$ until extraction. A geographical reference consisting of longitude, latitude and elevation was recorded for each sample collected (Supplemental Table 1 ).

\section{Table 1}

Forest type, elevation, population density and arborescent species associated with seven Dioon edule populations

\begin{tabular}{|c|c|c|c|c|c|c|c|}
\hline \multirow[t]{2}{*}{ Code } & \multirow[t]{2}{*}{ Population } & \multirow{2}{*}{$\begin{array}{l}\text { Forest } \\
\text { type }\end{array}$} & \multirow{2}{*}{$\begin{array}{l}\text { Elevation } \\
\text { range } \\
\text { (masl) }\end{array}$} & \multirow{2}{*}{$\begin{array}{l}\text { Population } \\
\text { density } \\
\text { (ind/ha)* }\end{array}$} & \multicolumn{3}{|c|}{ Associated tree species* } \\
\hline & & & & & $\begin{array}{l}\text { Quercus } \\
\text { laeta }\end{array}$ & $\begin{array}{l}\text { Brahea } \\
\text { dulcis }\end{array}$ & $\begin{array}{l}\text { Bursera } \\
\text { simaruba }\end{array}$ \\
\hline A & $\begin{array}{l}\text { Agua de } \\
\text { Gamotes }\end{array}$ & Oak & $999-1053$ & 3325 & $\mathrm{x}$ & & \\
\hline B & Los Anteojos & Oak & $1039-1058$ & 2700 & $\mathrm{x}$ & $\mathrm{x}$ & \\
\hline $\mathrm{C}$ & El Chijol & Oak & $727-784$ & 2150 & $\mathrm{x}$ & $\mathrm{x}$ & \\
\hline D & Los Pocitos & Oak & $772-780$ & 2100 & $\mathrm{x}$ & $\mathrm{x}$ & \\
\hline E & $\begin{array}{l}\text { Rincón de } \\
\text { los Naranjos }\end{array}$ & LTD & 388-399 & 1075 & & $\mathrm{x}$ & $\mathrm{x}$ \\
\hline $\mathrm{F}$ & $\begin{array}{l}\text { San Nicolas } \\
\text { de los } \\
\text { Montes }\end{array}$ & $\begin{array}{l}\text { LTD, } \\
\text { Oak }\end{array}$ & 834-944 & - & $\mathrm{x}$ & $\mathrm{x}$ & $\mathrm{x}$ \\
\hline G & Saucillos & Oak & $889-893$ & 3775 & $\mathrm{x}$ & & \\
\hline
\end{tabular}

LTD Low tropical deciduous forest

*As described in Rubio-Méndez (2010) 

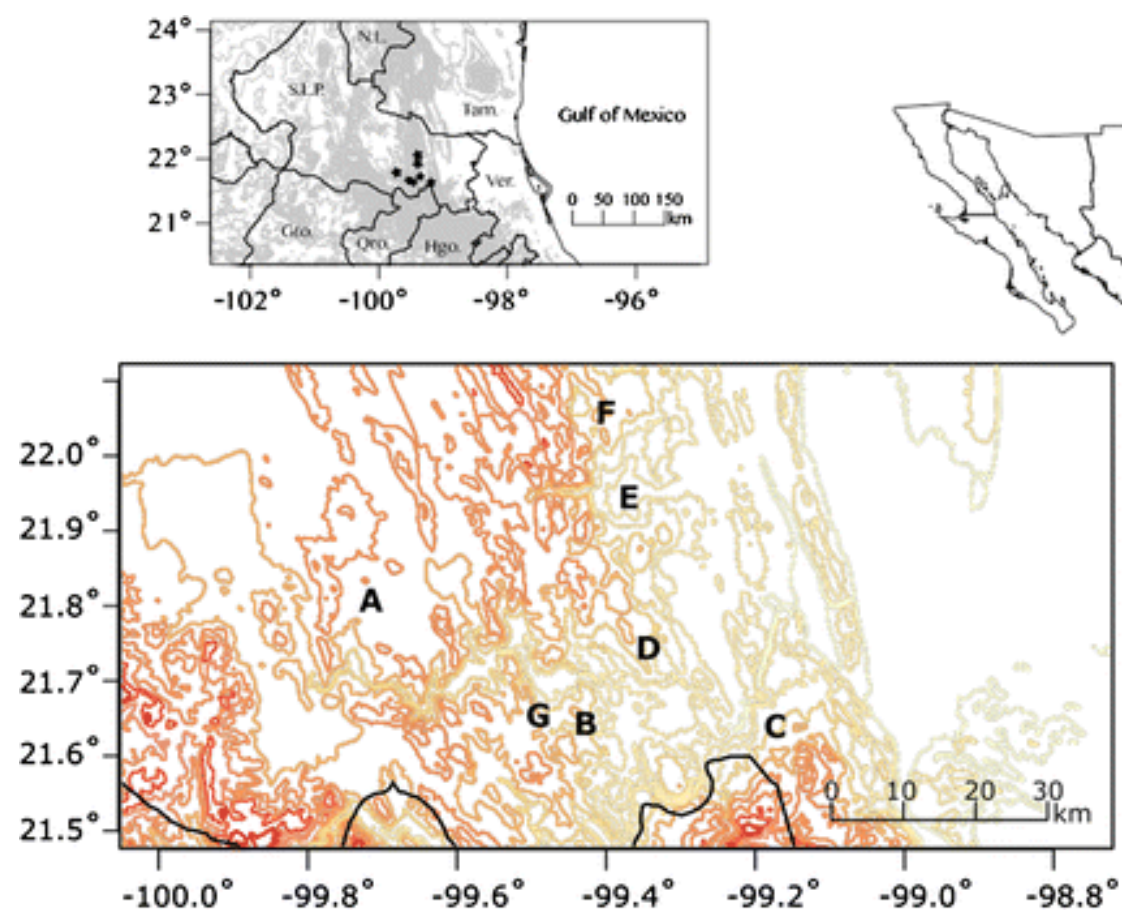

Fig. 1

Map of the seven Dioon edule populations in Northeastern Mexico. Stars and letters represent the different localities sampled. A- Agua de Gamotes, B- Los Anteojos, C- El Chijol, D- Los Pocitos, ERincón de los Naranjos, F- San Nicolas de los Montes, G- Saucillos

\section{Genotyping Genomic D. edule}

DNA was extracted from 147 D. edule individuals using the DNeasy kit (Qiagen) to extract $200 \mathrm{mg}$ tissue, following the manufacturer's protocols with minor modifications. Leaflets were ground in liquid nitrogen and sieved through a $0.5 \mathrm{~mm}$ mesh to remove cuticle and fiber particles. Eleven microsatellite markers were used for genotyping (Supplemental Table 2); four markers described by Moynihan et al. (2007) and 7 by Prado et al. (2016). Forward primers contained a 5'-extension of M13. We used an infrared dye-labeled (LI-COR Biosciences, Lincoln, NE, USA) M13(-29) sequence

(CACGACGTTGTAAAACGAC) as described in Prado et al. (2016). Microsatellite amplicons were analyzed and scored (fragment length) on a Li-Cor 4300 DNA Analyzer using SAGA version 2.0. Thus, each genotype is represented by amplicon sizes for both alleles at each of the 11 loci.

\section{Genetic Analysis}

Population genetic structure was assessed first graphically by using agglomerative hierarchical clustering (AGNES) of the genetic distances of individuals using the package Cluster in R (Kaufman and Rousseeuw 2009), then by Principal Component Analysis (PCA) of a correlation matrix of the genotypes using the packages ade4 and adegenet in R, with the function dudi.pca (Jombart 2008). Finally, population structure was assessed by using the software STRUCTURE and STRUCTURE Harvester (Earl and vonHoldt 2012; Pritchard et al. 2000). To evaluate genetic isolation by distance (IBD), a Mantel test was performed between the geographic distance matrix and genetic distance (pairwise genetic distance) matrixes with the package vegan using the function mantel (Dixon 2003). Genetic distance between individuals was calculated as the codominant genotypic distance following 
Smouse and Peakall (1999). Observed and expected heterozygosity were calculated per age cohort (Table 2). Individual heterozygosity was calculated as the proportion of heterozygous loci, PHt.

Table 2

Genetic diversity of the cycad Dioon edule in the Huasteca Potosina, Mexico

\begin{tabular}{|c|c|c|c|c|c|}
\hline Code & Life stage & $N$ & NA & HO & HE \\
\hline \multirow[t]{3}{*}{ A } & Seedling & 7 & $3.20 \pm 0.57$ & $0.45 \pm 0.145$ & $0.51 \pm 0.079$ \\
\hline & Juvenile & 7 & $2.73 \pm 0.49$ & $0.363 \pm 0.089$ & $0.39 \pm 0.073$ \\
\hline & Adult & 7 & $2.90 \pm 0.53$ & $0.349 \pm 0.108$ & $0.42 \pm 0.084$ \\
\hline \multirow[t]{3}{*}{ B } & Seedling & 7 & $3.09 \pm 0.56$ & $0.403 \pm 0.104$ & $0.44 \pm 0.092$ \\
\hline & Juvenile & 7 & $3.45 \pm 0.41$ & $0.53 \pm 0.108$ & $0.62 \pm 0.038$ \\
\hline & Adult & 7 & $3.27 \pm 0.36$ & $0.474 \pm 0.109$ & $0.53 \pm 0.053$ \\
\hline \multirow[t]{3}{*}{$\mathrm{C}$} & Seedling & 7 & $3.82 \pm 0.501$ & $0.539 \pm 0.097$ & $0.62 \pm 0.052$ \\
\hline & Juvenile & 7 & $3.64 \pm 0.36$ & $0.483 \pm 0.079$ & $0.60 \pm 0.037$ \\
\hline & Adult & 7 & $3.45 \pm 0.47$ & $0.364 \pm 0.1$ & $0.54 \pm 0.08$ \\
\hline \multirow[t]{3}{*}{$\mathrm{D}$} & Seedling & 7 & $3.27 \pm 0.45$ & $0.515 \pm 0.103$ & $0.50 \pm 0.071$ \\
\hline & Juvenile & 7 & $3.55 \pm 0.51$ & $0.516 \pm 0.086$ & $0.56 \pm 0.059$ \\
\hline & Adult & 7 & $3.27 \pm 0.36$ & $0.488 \pm 0.103$ & $0.51 \pm 0.052$ \\
\hline \multirow[t]{3}{*}{ E } & Seedling & 7 & $3.82 \pm 0.55$ & $0.595 \pm 0.114$ & $0.54 \pm 0.078$ \\
\hline & Juvenile & 7 & $3.55 \pm 0.49$ & $0.46 \pm 0.112$ & $0.55 \pm 0.08$ \\
\hline & Adult & 7 & $3.55 \pm 0.41$ & $0.461 \pm 0.094$ & $0.53 \pm 0.071$ \\
\hline \multirow[t]{3}{*}{$\mathrm{F}$} & Seedling & 7 & $4.00 \pm 0.94$ & $0.519 \pm 0.108$ & $0.51 \pm 0.094$ \\
\hline & Juvenile & 7 & $3.20 \pm 0.57$ & $0.358 \pm 0.103$ & $0.48 \pm 0.072$ \\
\hline & Adult & 7 & $3.09 \pm 0.55$ & $0.468 \pm 0.107$ & $0.52 \pm 0.058$ \\
\hline
\end{tabular}




\begin{tabular}{|l|l|l|l|l|l|}
\hline Code & Life stage & $\boldsymbol{N}$ & NA & HO & HE \\
\hline G & Seedling & 7 & $3.00 \pm 0.40$ & $0.305 \pm 0.089$ & $0.52 \pm 0.05$ \\
\cline { 2 - 6 } & Juvenile & 7 & $3.64 \pm 0.47$ & $0.439 \pm 0.106$ & $0.55 \pm 0.074$ \\
\cline { 2 - 6 } & Adult & 7 & $3.36 \pm 0.47$ & $0.425 \pm 0.11$ & $0.55 \pm 0.071$ \\
\hline \multirow{2}{*}{ Mean } & Seedling & 49 & $3.46 \pm 0.15$ & $0.475 \pm 0.037$ & $0.52 \pm 0.02$ \\
\cline { 2 - 6 } & Juvenile & 49 & $3.39 \pm 0.12$ & $0.45 \pm 0.026$ & $0.53 \pm 0.029$ \\
\cline { 2 - 6 } & Adult & 49 & $3.27 \pm 0.08$ & $0.433 \pm 0.021$ & $0.51 \pm 0.016$ \\
\hline
\end{tabular}

Mean number of alleles per locus (Na), mean observed heterozygocity (Ho), and mean expected heterozygocity $(\mathrm{He}) \pm$ standard error

\section{Chemical Analysis}

The thick, waxy cuticle that characterizes Dioon leaflets can hamper the extraction of metabolites and DNA. Leaflet samples representing each one of the 147 individuals were lyophilized and ground in liquid nitrogen. The powdered leaflets were sieved through a $0.5 \mathrm{~mm}$ mesh to remove cuticle pieces and most fibers. The remaining green powder largely comprised of leaf mesoderm was used for pigment and AZG analysis.

To assess the photosynthetic capacity of the cycad leaves at different ontogenetic stages, chlorophyll $_{\mathrm{a}}$ and $\mathrm{b}_{\mathrm{b}}$ as well as the carotenoid lutein were quantified. For chlorophyll quantification, $100 \mathrm{mg}$ of ground tissue were suspended in $1 \mathrm{ml}$ of $80 \%$ acetone, maintained on ice for $30 \mathrm{~min}$, and then centrifuged at $6000 \mathrm{rpm}$ for $1 \mathrm{~min}$. The supernatant was analyzed spectrophotometrically (Tecan Infinite M200 Pro) at 646 and $663 \mathrm{~nm}$ and chlorophyll ${ }_{\mathrm{a}}$ and chlorophyll $\mathrm{b}$ content were calculated according to Wellburn (1994). Lutein is the most abundant carotenoid in photosynthetic tissues and plays an important role in the photoprotection of the photosystem (Baroli and Niyogi 2000). Lutein was extracted from $100 \mathrm{mg}$ of tissue in $1 \mathrm{ml}$ of acetone/ethanol $\left(1: 1 \mathrm{v} / \mathrm{v}\right.$, with $1 \mu \mathrm{g} / \mathrm{ml}$ of trans- $\beta$-apo- $8^{\prime}-$ carotenal as the internal standard). Samples were maintained for $15 \mathrm{~min}$ at room temperature and centrifuged for $10 \mathrm{~min}$ at $8000 \mathrm{rpm}$. Lutein was quantified by HPLC following Seguin et al. (2011). Lutein standard $(96.6 \% \mathrm{w} / \mathrm{w}$, ChromaDex, Irvine, CA, USA) was used to prepare a calibration curve.

As Prado et al. (2014) found low AZG levels $(\approx 0.46 \mu \mathrm{mol} / \mathrm{g} \mathrm{FW})$ in mature leaves of the cycad $Z$. stevensonii, the extraction protocol for AZGs was modified to include a second extraction step. One hundred $\mathrm{mg}$ of mesoderm tissue were extracted in $1.5 \mathrm{ml}$ of $70 \%$ ice-chilled ethanol (EtOH), and vigorously vortexed using a tissue disrupter for $4 \mathrm{~min}$. Samples were incubated on ice for $20 \mathrm{~min}$ and then centrifuged at 13,200 rpm for $10 \mathrm{~min}$. The supernatant was transferred to a new vial. The pellet was re-suspended in an additional $1 \mathrm{ml} 70 \% \mathrm{EtOH}$, vortexed, and centrifuged at 13,200 rpm for $10 \mathrm{~min}$. Supernatants were combined and an equal volume of water was added before freeze-drying. Lyophilized samples were re-suspended in $25 \mathrm{mM}$ sodium acetate buffer solution, $\mathrm{pH} 5$. In parallel, two aliquots of each sample were diluted 6.5 times in sodium acetate buffer; one aliquot was incubated overnight at room temperature with $\beta$-glycosidase ( $0.5 \mathrm{U}$; Sigma-Aldrich, St. Louis, MO, USA), and the other aliquot was incubated without enzyme. $\beta$-lycosidase cleaves the sugar off the AZGs to generate the methylazoxymethanol (MAM) core. AZGs were quantified by MAM equivalents by HPLC 
on a reverse-phase HI-Plex Na (Octo) column $(300 \times 7.7 \mathrm{~mm}$, Agilent) using an isocratic elution of $100 \%$ water at a flow rate of $0.45 \mathrm{ml} / \mathrm{min}$ at $65^{\circ} \mathrm{C}$ (Prado et al. 2011; Yagi 2004). Compounds were detected by a photodiode array detector at $215 \mathrm{~nm}$. The MAM peak in the samples was identified on the basis of retention time, and confirmed by the increase and loss of the AZG peaks (cycasin and macrozamin) in the $\beta$-glycosidase-treated subsample (Prado et al. 2011). MAM was quantified based on the peak area and in relation to the seven point standard curve prepared with MAM acetate (National Cancer Institute, Washington, D.C., USA), which was converted into MAM by incubation with an esterase enzyme (Sigma-Aldrich) in $1 \mathrm{M}$ Tris-HCl buffer, $\mathrm{pH} 8.5$, for $1 \mathrm{~h}$ at room temperature.

\section{Statistical Analysis}

Mantel tests were used to quantify the relationship between plant genetics and plant chemistry by age cohort using the mantel function of the vegan package in $\mathrm{R}$. The chemical data were natural log transformed before the calculation of the Euclidean distance matrixes. Distance matrixes on the chemical data were compared to an individual by individual genetic distance matrix and an Euclidean distance matrix of the proportion of heterozygous loci (PHt). Pearson correlation values between the standardized elements of the matrices (Rxy) based on 999 permutations and their associated significance values were used to assess these correlations (Supplemental Table $\underline{3}$ ).

Difference in pigment levels between the ontogenetic cohorts was assessed by a one-way ANOVA followed by Tukey HSD (honestly significant difference) post hoc test to identify significant differences. As the distribution of AZG data was skewed (Shapiro-Wilk normality test, $P<0.001$ ) and as there was a heterogeneity of variance across age categories (Bartlett homogeneity of variance test, $P<0.001$ ), a Kruskal-Wallis Rank Sum test was performed to test for differences in AZG levels, first on the complete data set followed by multiple comparisons. Additionally, the relationship between previous number of crowns (as a proxy of plant age) and AZG content for males and females was analyzed by fitting linear models. To have data near the origin for these linear models, all seedling and juvenile data were included in both male and female models.

\section{Results}

\section{Population Structure}

Based on the Mantel tests between the geographic distance matrix and genetic distance matrixes (by individuals or by site), there is no indication of isolation by distance (Fig. 2). The maximum distance between the individuals sampled is $\approx 60 \mathrm{~km}$. Overall, the genetic diversity is relatively homogenous across populations (Table 2). The effective number of alleles and observed heterozygosity (Ho) measured is relatively homogenous across all sites, ranging from 2.72-4 and 0.305-0.595, respectively.

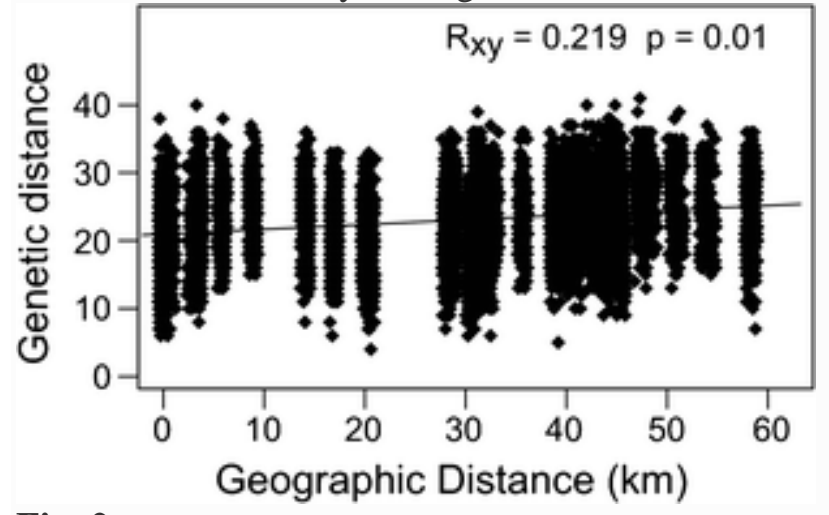

Fig. 2 
Isolation by distance plot. The geographical distance between Dioon edule individuals is weakly correlated to their genetic distance. Genetic distance was calculated as a multilocus additive distance as described by Smouse and Peakall (1999)

For the eleven microsatellite loci used in this study (Supplemental Table 2), genetic diversity was found to decrease moderately with plant age. An average number of alleles of 3.46 and an observed heterozygosity of 0.475 was recorded for the seedling cohort (Table 2), and then fell to 3.27 alleles and 0.433 observed heterozygosity in adult plants. These results are in accordance with the population structure of this species, with a high mortality occurring at the seedling stage. The stronger selection at the seedling stage reduces the overall genetic diversity.

While no evidence for isolation by distance was found, STRUCTURE analysis revealed the existence of three genetic clusters (Supplemental Figs. 1, 2a, b). The AGNES clustering (Supplemental Fig. 1) and the PCA on the genotypes revealed that the genotypes could be grouped in two major groups representing highland and lowland individuals, while the remaining smaller group is a mixture of both highland and lowland individuals (Fig. $\underline{3}$ ). Hence, the genotypes follow an altitudinal pattern with highland individuals ( $>800$ masl) being to some extent distinct to lowland individuals ( $<800$ masl). This result led us to consider these two groups as separate for the analysis of AZG levels.

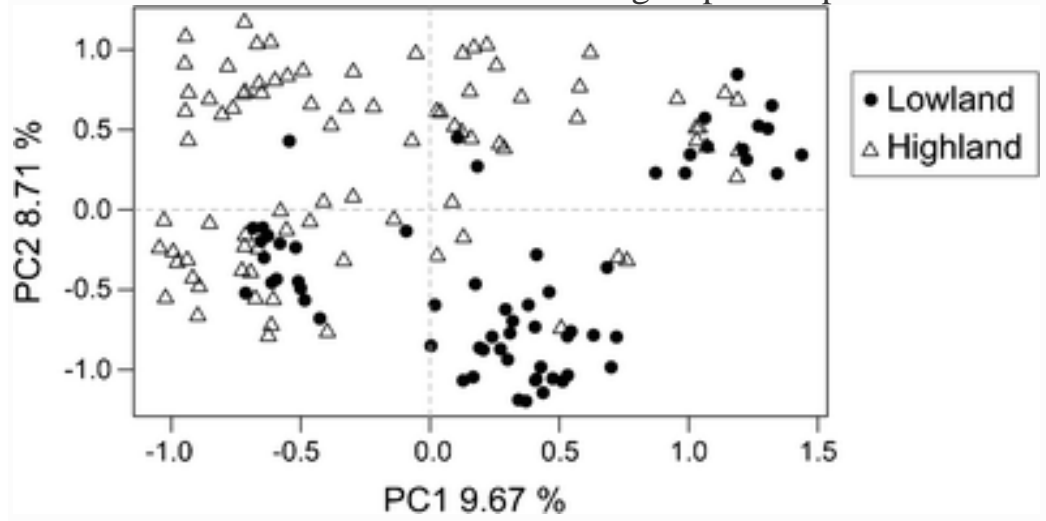

Fig. 3

Principal component analysis of Dioon edule genotypes in relation to altitude. Lowland individuals are those below 800 masl and highland individuals are those above 800 masl. Principal components 1 and 2 account for $18.38 \%$ of the variation of the genotypes

Pigments

Nitrogen deficiency can negatively affect chlorophyll biosynthesis and, therefore, levels of these photosynthetic pigments reflect leaf nutritional quality (Liu et al. 2006). Chlorophylla, chlorophyll b, and lutein levels ranged from $0.16-0.77 \mu \mathrm{g} / \mathrm{mg}, 0.13-0.62 \mu \mathrm{g} / \mathrm{mg}$, to $0.06-0.6 \mu \mathrm{g} / \mathrm{mg}$, respectively, in $D$. edule leaves (Fig. 4a). Pigment concentrations in the leaves remained stable throughout the ontogenetic stages of $D$. edule, except chlorophyll a content, that was higher in seedlings compared to adult cycads. The levels of these three pigments were not correlated to plant genotype or individual heterozygosity (Supplemental Table 2). All correlations between plant genetics and plant chemistry were weak $($ Rxy $<|0.29|)$, and with the exception of the weak correlation between chlorophyll $\mathrm{b}$ and PHt in seedlings $(\mathrm{Rxy}=0.28, P<0.01)$ and also between AZGs and PHt in adults (Rxy $=0.165, P<0.05)$, none of the correlations was significant (Supplemental Table $\underline{3}$ ). 

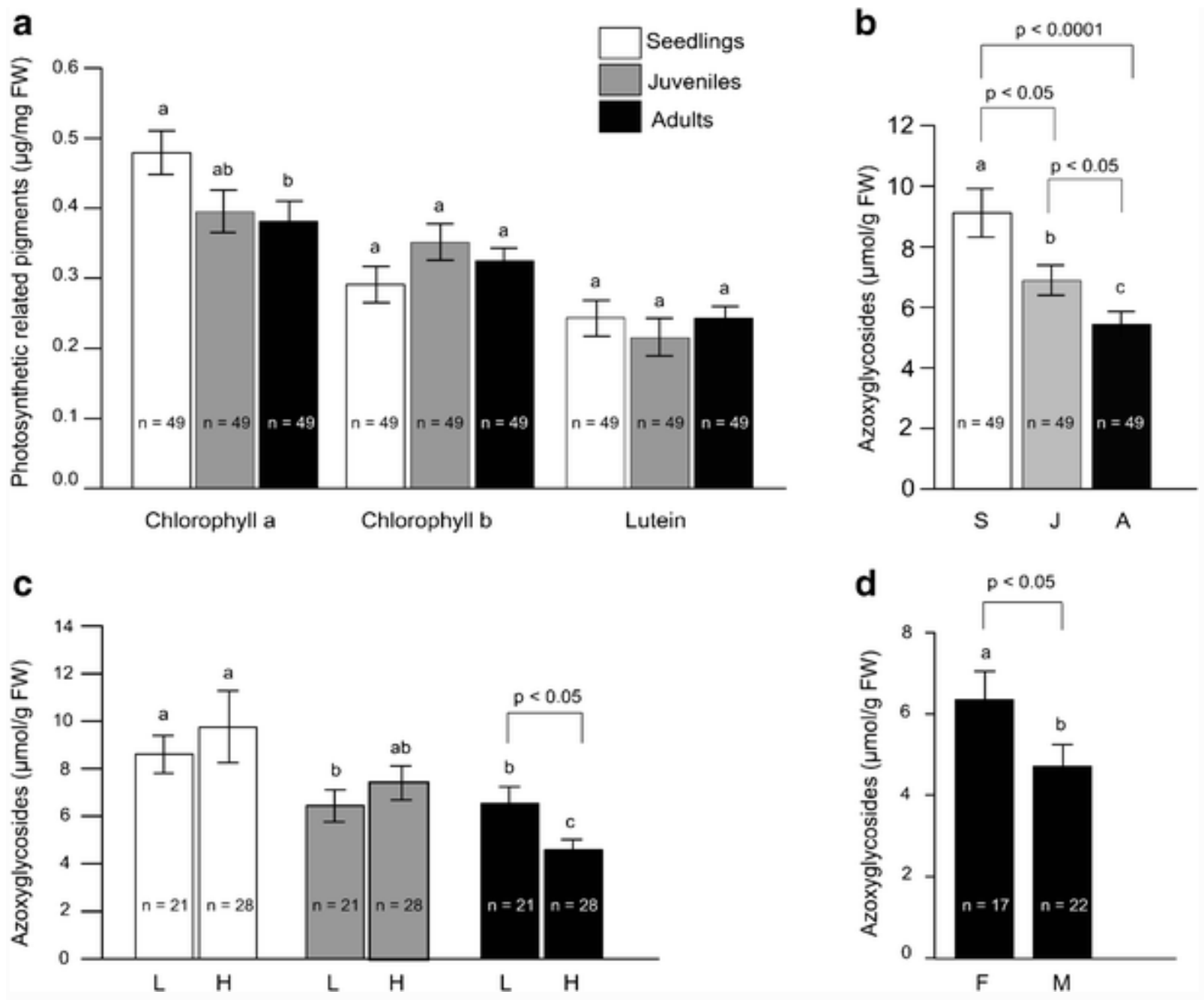

Fig. 4

Photosynthetic pigment and azoxyglycoside (AZG) levels in Dioon edule leaves in relation to ontogenetic stage and sex. A) Levels of photosynthetic pigments, chlorophyll ${ }_{\mathrm{a}}$, chlorophyll $\mathrm{b}_{\mathrm{b}}$ and lutein in seedling, juvenile and adult cycad leaves. B) Foliar AZG levels in cycad seedlings (S), juveniles (J), and adults (A). C) Foliar AZG levels in lowland (L, <800 masl) and highland (H, >800 masl) cycads. D) Foliar AZG levels in female (F) and male (M) adult cycads. White bars are seedlings, grey are juveniles and black are adults. Lines represent the standard error of the mean. The number of biological samples $(\mathrm{N})$ analyzed is found in the bar graph insert

Azoxyglycosides

AZG levels in fully developed $D$. edule leaves ranged from 1.52 to $26.51 \mu \mathrm{mol} / \mathrm{g}$ fresh weight (Fig. $\underline{5}$ ). These levels are comparable to other cycads. For example, Z. stevensonii mature leaves contain in average $0.46 \mu \mathrm{mol} / \mathrm{g}$ fresh weight (Prado et al. 2014). Yagi (2004) found that leaves of several cycad species contain AZG levels of 3.9-79.29 $\mu \mathrm{mol} / \mathrm{g}$. As mentioned, the observed variation in AZG levels in D. edule leaves was not correlated to plant genotype or to the individual heterozygosity of each plant according to standardized Rxy values of the Mantel tests (Supplemental Table $\underline{3}$ ). 


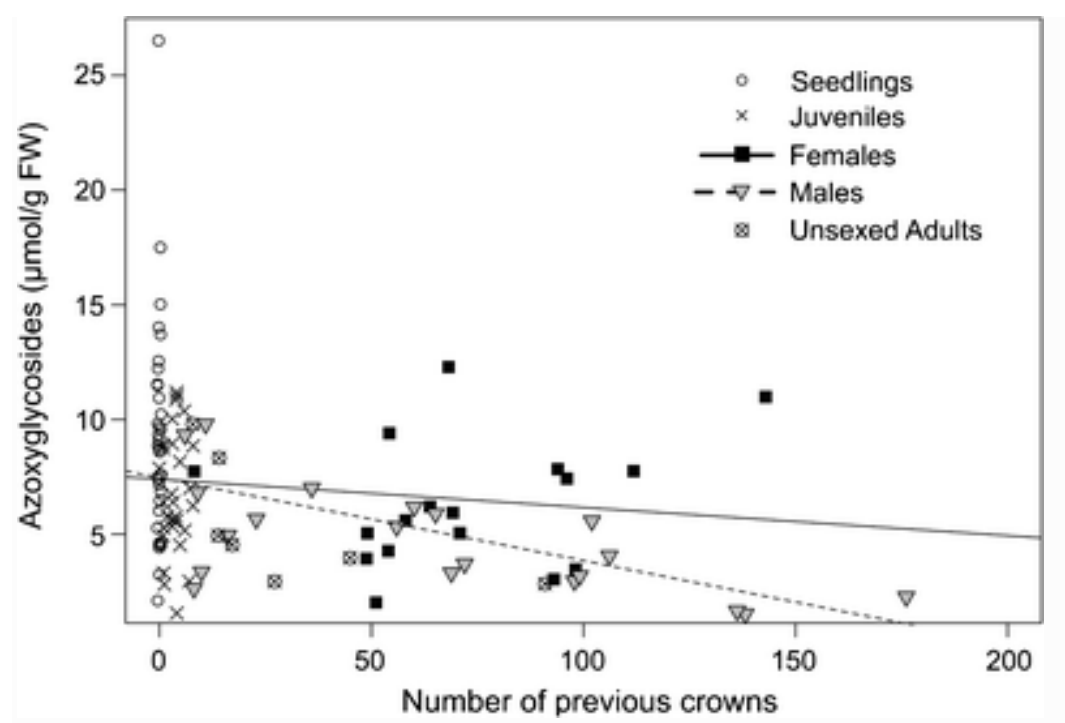

Fig. 5

Relationship between cycad age and leaf azoxyglycoside (AZG) content. The number of leaf crowns was used as a proxy for cycad age. AZG levels are lower in older plants; this decrease is more pronounced in adult male (slope of the linear regression of AZG content - 0.043 ) compared to female (slope of the linear regression of AZG content -0.016) cycads. Seedling and juvenile data are included in both linear regressions to provide a reference near the origin

A negative relationship was observed between plant age and AZG content (Fig. 4 b). Seedlings contained the highest AZG levels with an average of $9.11 \mu \mathrm{mol} / \mathrm{g} \mathrm{FW}$ followed by juveniles, with an average of $6.86 \mu \mathrm{mol} / \mathrm{g} \mathrm{FW}$, and was lower in adult plants with an average of $5.43 \mu \mathrm{mol} / \mathrm{g} \mathrm{FW}$. These differences were supported by pairwise Kruskal-Wallis Rank Sum tests. The same pattern is observed if the data are separated into high and lowland individuals (Fig. $\underline{4}$ ).

Focusing on adult cycads, lower AZG levels were found in the leaves of males compared to females (Fig. 4d). Male leaves contained an average of $4.72 \mu \mathrm{mol} / \mathrm{g} \mathrm{FW}$, while female leaves contained $6.35 \mu \mathrm{mol} / \mathrm{g} \mathrm{FW}$. As plants age (as estimated by counting the girdling scars on the cycad's trunk), AZGs levels in leaves decreased more quickly in male (slope of the linear regression of AZG content -0.043 ) than female (slope of the linear regression of AZG content -0.016) cycads (Fig. 5).

We found $42 \%$ higher AZG levels in lowland adult individuals when compared to highland adults (Fig. 4c). Highland adults contained an average of $4.56 \mu \mathrm{mol} / \mathrm{g} \mathrm{FW}$, while lowland adults had an average of $6.51 \mu \mathrm{mol} / \mathrm{g} \mathrm{FW}$. This difference was not due to a higher proportion of females sampled in the lowland group. The ratios between sexed individuals in highland and lowland sites were similar (7 females and 9 males sampled in lowland sites and 10 females and 13 males sampled in the highland sites).

\section{Discussion}

We examined chemical and genotypic variation in D. edule individuals from the Huasteca Potosina, Mexico. We found evidence of differentiation between lowland and highland individuals, which supports the distinction of lowland and highland forms recognized by Whitelock (2004). The genotypic differentiation is matched by a difference in AZG content in adult plants, where lowland individuals produce higher levels of toxins compared to highland individuals. Since there is strong evidence of gene flow and consistent levels of genetic diversity across sites, the genetic and chemical variation 
observed between highland and lowland sites most probably is explained by environmental differences rather than isolation.

Plant genetics did not explain the variation in leaf chemistry at the individual level. Pigment concentrations and AZG content are not correlated with heterozygosity or with genotype. However, the 11 microsatellite markers used were from noncoding regions of the genome, which might explain this lack of correlation between plant genetics and leaf chemistry.

Young seedling cycads only bear one or two leaves in their first 3-5 years. The mortality rate during this initial life stage is high, mainly due to drought and herbivory (Mora et al. 2013; Vovides 1990; Yáñez-Espinosa et al. 2014). Compared to adult plants, leaves in these young plants have higher levels of chlorophyll ${ }_{a}$, indicating higher nutritional quality for insect herbivores (Liu et al. 2006), and higher AZG levels, possibly for protection (Figs. $\underline{4}, \underline{5}$ ). Foliar AZG defenses decrease as plants age; on average, leaf AZG levels in seedlings are $68 \%$ higher than in adults. Therefore, high concentrations of toxic metabolites seem most advantageous at this stage to protect tissues with high photosynthetic potential and a high value to seedling survival.

In a study on leaf production and reproductive cost in the cycad Zamia skinneri, Clark and Clark (1988) found strong differences in reproductive costs between female and male cycads; leaf production in females was depressed for two years after cone formation, thus implying higher costs associated with female reproduction (Clark and Clark 1988). As in Z. skinneri, the difference in the physiological costs of reproduction between males and females could be a determining factor in the frequency of leaf production in $D$. edule, with females producing leaves less frequently than males (Clark and Clark 1988). Vovides (1990) estimated cone production frequencies in D. edule to be 2.8-8.8 years in males compared to 10.0-52.0 years in females. We observed a clear difference in AZG content in the leaves of $D$. edule in relation to sex, with females having $38 \%$ higher AZG content than males. The difference observed could be associated with costs of reproduction. Male individuals with lower reproduction costs are able to produce leaves more often and possibly withstand higher levels of herbivory than females. A few studies on dioecious woody angiosperms have found female individuals better defended against herbivores than male plants (Boecklen and Hoffman 1993; Jing and Coley 1990). In our study sites, female and male $D$. edule had similar total numbers of leaves $(25.2 \pm 2.3$ and $22.7 \pm 1.9$, respectively, Supplemental Table $\underline{3})$. Mechanisms that alleviate the costs of reproduction have been identified in several dioecious species (Obeso 2002). The longer intervals between cone formation in females could be a mechanism to alleviate reproductive costs. Other mechanisms include changes in assimilate demand that can result in changes in photosynthetic rates (Obeso 2002; Wardlaw 1990). For example, female Ginkgo plants have higher photosynthetic rates than males (Jing et al. 2008). It is unknown if a similar compensatory mechanisms exists in cycads.

In summary, our results show that the AZG content in D. edule leaves changes as plants age, and is different between sexes. Our results are compatible with the Optimal Defense Hypothesis (Rhoades and Cates 1976); the consequences of losing a leaf at the seedling stage represents a greater risk than losing a leaf at the adult stage, hence, seedlings are better chemically defended than adults. As plants grow, they increase their tolerance to herbivory and are able to invest more in mechanical defenses that are effective even against specialist herbivores (Prado et al. 2014). Therefore, as leaf and root resources increase, the need to chemically defend leaves decreases. If costs associated with female reproduction are indeed higher in cycads, the Optimal Defense Hypothesis also could explain observed sex differences in AZG levels. Males with lower costs can withstand higher herbivory levels and, hence, invest less in chemical defense. Future studies of cycads should evaluate insect damage, preference and performance on different ontogenetic stages and sexes. 


\section{Acknowledgments}

We thank Marc Hersh, Gabriel Gálvez, Andrés Everaert and Hugo Lagarto Castillo for assistance in the field and the laboratory. We thank Don Windsor for mentorship and two anonymous reviewers for beneficial comments. This research was funded through the Consejo Nacional de Ciencia y Tecnología (Mexico) (AP, GR-M and LY-E) and the Natural Sciences and Engineering Research Council of Canada (JCB).

\section{Supplemental Material}

10886_2016_774_MOESM1_ESM.docx $(2 \mathrm{mb})$

Supplemental Figure 1(DOCX $2080 \mathrm{~kb}$ )

108862016774 MOESM2 ESM.docx $(342 \mathrm{~kb})$

Supplemental Figure 2(DOCX $341 \mathrm{~kb})$

10886_2016_774_MOESM3_ESM.docx $(36 \mathrm{~kb})$

Supplemental Table 1(DOCX $36 \mathrm{~kb})$

108862016774 MOESM4 ESM.docx $(61 \mathrm{~kb})$

Supplemental Table 2(DOCX $61 \mathrm{~kb})$

10886_2016_774_MOESM5_ESM.docx (40 kb)

Supplemental Table 3(DOCX $39 \mathrm{~kb})$

\section{References}

1. Baroli I, Niyogi KK (2000) Molecular genetics of xanthophyll-dependent photoprotection in green algae and plants. Philos Trans R Soc 355:1385-1394

2. Bello-Bedoy R, Núñez-Farfán J (2011) The effect of inbreeding on defence against multiple enemies in Datura stramonium. J Evol Biol 24:518-530

3. Boecklen WJ, Hoffman MT (1993) Sex-biased herbivory in Ephedra trifurca: the importance of sex-by-environment interactions. Oecologia 96:49-55

4. Boege K (2005) Herbivore attack in Casearia nitida influenced by plant ontogenetic variation in foliage quality and plant architecture. Oecologia 143:117-125

5. Boege K, Marquis RJ (2005) Facing herbivory as you grow up: the ontogeny of resistance in plants. Trends Ecol Evol 20:441-448

6. Bowers MD, Larin Z (1989) Acquired chemical defense in the lycaenid butterfly, Eumaeus atala. J Chem Ecol 15:1133-1146

7. Bowers MD, Stamp NE (1993) Effects of plant age, genotype and herbivory on Plantagoperformance and chemistry. Ecology 74:1778-1791 
8. Castillo-Guevara C, Rico-Gray V (2003) The role of macrozamin and cycasin in cycads (Cycadales) as antiherbivore defenses. J Torrey Bot Soc 130:206-217

9. Clark DB, Clark DA (1988) Leaf production and the cost of reproduction in the Neotropical rain forest cycad, Zamia skinneri. J Ecol 76:1153-1163

10. Clark DB, Clark DA (1991) Herbivores, herbivory, and plant phenology: Patterns and consequences in a tropical rain-forest cycad. In: Price PW, Lewinsohn TM, WilsonFernandes G, Benson WW (eds) Plant-animal interactions: Evolutionary ecology in tropical and temperate regions. John Wiley \& Sons, New York, pp. 209-255

11. Claydon $\mathbf{N}$ (1978) Insecticidal secondary metabolites from entomogenous fungi: Entomophthora virulenta. J Invertebr Pathol 32:319-324

12. Deevey E (1947) Life tables for natural populations of animals. Q Rev Biol 22:283-314

13. Ding L, Ndejouong BLST, Maier A, Fiebig H-H, Hertweck C (2012) Elaiomycins D-F, antimicrobial and cytotoxic azoxides from Streptomyces sp. strain HKI0708. J Nat Prod 75:1729-1734

14. Dixon $P$ (2003) VEGAN, a package of $R$ functions for community ecology. J Veg Sci 14:927-930

15. Dominy NJ, Lucas PW, Wright SJ (2003) Mechanics and chemistry of rain forest leaves: Canopy and understory compared. J Ex Bot 54:2007-2014

16. Earl DA, vonHoldt BM (2012) STRUCTURE HARVESTER: a website and program for visualizing STRUCTURE output and implementing the Evanno method. Conserv Genet Resour 4:359-361

17. Erelli MC, Ayres MP, Eaton GK (1998) Altitudinal patterns in host suitability for forest insects. Oecologia 117:133-142

18. González-Astorga J, Vovides A, Ferrer M, Iglesias C (2003) Population genetics of Dioon edule Lindl. (Zamiaceae, Cycadales): Biogeographical and evolutionary implications. Biol J Linn Soc 80:457-467

19. Goodger JQ, Ades PK, Woodrow IE (2004) Cyanogenesis in Eucalyptus polyanthemosseedlings: heritability, ontogeny and effect of soil nitrogen. Tree Physiol 24:681-688

20. Jing SW, Coley PD (1990) Dioecy and herbivory: the effect of growth rate on plant defense in Acer negundo. Oikos 58:369-377

21. Jing J, Hong J, Shuquan Y, Guomo Z (2008) Sex-linked photosynthetic physiologic research and the evolutionary ecological analysis in living fossil plant, Ginkgo biloba L. Acta Ecol Sin 28:1128-1136

22. Johnson M, Smith S, Rausher M (2009) Plant sex and the evolution of plant defenses against herbivores. Proc Natl Acad Sci U S A 106

23. Jombart $\mathbf{T}$ (2008) Adegenet: a $\mathbf{R}$ package for the multivariate analysis of genetic markers. Bioinformatics 24:1403-1405 
24. Kariyat RR, Balogh CM, Moraski RP, De Moraes CM, Mescher MC, Stephenson AG (2013) Constitutive and herbivore-induced structural defenses are compromised by inbreeding in Solanum carolinense (Solanaceae. Am J Bot 100:1014-1021

25. Kaufman L, Rousseeuw PJ (2009) Finding groups in data: An introduction to cluster analysis. John Wiley \& Sons, New York

26. Laqueur GL, Spatz M (1968) Toxicology of cycasin. Cancer Res 28:2262-2267

27. Liu Y-J, Tong Y-P, Zhu Y-G, Ding H, Smith FA (2006) Leaf chlorophyll readings as an indicator for spinach yield and nutritional quality with different nitrogen fertilizer applications. J Plant Nutr 29:1207-1217

28. Lloyd DG, Webb C (1977) Secondary sex characters in plants. Bot Rev 43:177-216

29. Matsushima T, Matsumoto H, Shirai A, Sawamura M, Sugimura T (1979) Mutagenicity of the naturally occurring carcinogen cycasin and synthetic methylazoxymethanol conjugates in Salmonella typhimurium. Cancer Res 39:3780-3782

30. Mora R, Yáñez-Espinosa L, Flores J, Nava-Zárate N (2013) Strobilus and seed production of Dioon edule (Zamiaceae) in a population with low seedling density in San Luis Potosí, Mexico. Trop Conserv Sci 6:268-282

31. Moynihan J, Meerow AW, Francisco-Ortega J (2007) Isolation, characterization and cross-species amplification of microsatellite loci in the cycad genus Dioon (Zamiaceae). Potential utilization in population genetic studies of Dioon edule. Mol Ecol 7:72-74

32. Norstog KJ, Nicholls TJ (1997) The biology of the Cycads. Cornell University Press, New York

33. Obeso JR (2002) The costs of reproduction in plants. New Phytol 155:321-348

34. Ornduff $R$ (1987) Sex ratios and coning frequency of the cycad Zamia pumila L.(Zamiaceae) in the Dominican Republic. Biotropica 19:361-364

35. Prado A, Ledezma J, Cubilla-Rios L, Bede JC, Windsor D (2011) Two genera of Aulacoscelinae beetles reflexively bleed azoxyglycosides found in their host cycads. $\mathrm{J}$ Chem Ecol 37:736-740

36. Prado A, Sierra A, Windsor D, Bede JC (2014) Leaf traits and herbivory levels in a tropical gymnosperm, Zamia stevensonii (Zamiaceae). Am J Bot 101:437-447

37. Prado A, Cervantes-Díaz F, Perez-Zavala FG, González-Astorga J, Bede JC, CibriánJaramillo A (2016) Transcriptome-derived microsatellite markers for Dioon (Zamiaceae) cycad species. Appl Plant Sci 4

38. Pritchard JK, Stephens M, Donnelly P (2000) Inference of population structure using multilocus genotype data. Genetics 155:945-959

39. Puig H (1976) Végétation de la Huasteca, Mexique. Mission Archeologique et Ethnologique Français au Mexique, México

40. Rasmann S, Pellissier L, Defossez E, Jactel H, Kunstler G (2014) Climate-driven change in plant-insect interactions along elevation gradients. Funct Ecol 28:46-54 
41. Rhoades DF, Cates RG (1976) Toward a general theory of plant antiherbivore chemistry. Recent Adv Phytochem 10:168-213

42. Rubio-Méndez G (2010) Estructura poblacional de Dioon edule Lindl. (Zamiaceae) en la Sierra Madre Oriental del Estado de San Luís Potosí. Thesis. Universidad Autónoma de San Luís Potosí.

43. Schappert PJ, Shore JS (2000) Cyanogenesis in Turnera ulmifolia L.(Turneraceae): II. Developmental expression, heritability and cost of cyanogenesis. Evol Ecol Res 2:337-352

44. Schoonhoven LM, Van Loon JJ, Dicke M (2005) Insect-plant biology:. Oxford University Press, Oxford

45. Seguin P, Tremblay G, Pageau D, Liu W, Turcotte P (2011) Soybean lutein concentration: impact of crop management and genotypes. Crop Sci 51:1151-1160

46. Smouse PE, Peakall R (1999) Spatial autocorrelation analysis of individual multiallele and multilocus genetic structure. Heredity 82:561-573

47. Stamp N (2003) Out of the quagmire of plant defense hypotheses. Q Rev Biol 78:23-55

48. Strauss SY, Rudgers JA, Lau JA, Irwin RE (2002) Direct and ecological costs of resistance to herbivory. Trends Ecol Evol 17:278-285

49. Teas HJ, Dyson JG (1967) Mutation in Drosophila by methylazoxymethanol, the aglycone of cycasin. Proc Soc Exp Biol Med 125:998-990

50. Teas HJ, Dyson JG, Whisenant BR (1966) Cycasin metabolism in Seirarctia echo Abbot and Smith (Lepidoptera: Arctiidae). J GA. Entomol Soc 1:21-22

51. van Dam NM, Horn M, Mareš M, Baldwin IT (2001) Ontogeny constrains systemic protease inhibitor response in Nicotiana attenuata. J Chem Ecol 27:547-568

52. Vovides AP (1990) Spatial distribution, survival, and fecundity of Dioon edule (Zamiaceae) in a tropical deciduous forest in Veracruz, Mexico, with notes on its habitat. Am J Bot 77:1532-1543

53. Wardlaw IF (1990) Tansley review no. 27. The control of carbon partitioning in plants. New Phytol 116:341-381

54. Weiner $\mathbf{J}$ (2004) Allocation, plasticity and allometry in plants. Perspect Plant Ecol Evol Syst 6:207-215

55. Wellburn AR (1994) The spectral determination of chlorophyll a and b, as well as total carotenoids, using various solvents with spectrophotometer of different resolution. J Plant Physiol 144:307-313

56. Whitelock L (2004) Variation in the Mexican cycad Dioon edule (Zamiaceae). Bot Rev 70:240-249

57. Wimp G, Wooley S, Bangert R, Young W, Martinsen G, Keim P, Rehill B, Lindroth R, Whitham $\mathrm{T}$ (2007) Plant genetics predicts intra-annual variation in phytochemistry and arthropod community structure. Mol Ecol 16:5057-5069 
58. Yagi F (2004) Azoxyglycoside content and [beta]-glycosidase activities in leaves of various cycads. Phytochemistry 65:3243-3247

59. Yáñez-Espinosa L, Flores J, Rodríguez-Millan PS, Rubio-Méndez G (2014) Influence of germination date on Dioon edule (Zamiaceae) seedling tolerance to water stress. J Plant Res 127:413-422 